\title{
TWENTIETH-CENTURY ROMANCE AND GOTHIC WRITERS
}

\author{
PREFACE \\ KAY MUSSELL
}

EDITOR

JAMES VINSON

ASSOCIATE EDITOR

D.L. KIRKPATRICK

$\mathbf{M}$ 
๑ by Macmillan Publishers Limited, 1982

Softcover reprint of the hardcover 1st edition 1982

All rights reserved. No part of this publication may be reproduced or transmitted in any form or by any means, without permission.

First published 1982 by

MACMILLAN PUBLISHERS LIMITED (Journals Division)

Associated companies throughout the world

Distributed by Globe Books Services Ltd

Canada Road, Byfleet, Surrey KT14 7JL

ISBN 978-1-349-06129-7 ISBN 978-1-349-06127-3 (eBook)

DOI $10.1007 / 978-1-349-06127-3$ 


\section{CONTENTS}

PREFACE AND READING LIST

EDITOR'S NOTE

ADVISERS AND CONTRIBUTORS

TWENTIETH-CENTURY ROMANCE

AND GOTHIC WRITERS

TITLE INDEX

NOTES ON ADVISERS AND CONTRIBUTORS
737

page $\mathrm{v}$

xi

xiii

893 


\section{PREFACE}

The roots of gothic and romance fiction lie in the origins of the novel form itself. In the 18th and early 19th centuries, the two most prominent types of fiction - the seduction story and the gothic tale of terror-were the predecessors of today's romance fiction, and for two centuries writers on both sides of the Atlantic have written stories of romantic adventure that appealed to a largely middle-class audience. But as the novel form matured, the gothic and romantic subject matter was left behind, becoming the province of popular writers who continued to write such tales while more serious authors examined topics of a more universal character. Critics of early fiction often noted the high percentage of female readers for gothic and romance; but most serious novelists were male, addressing themselves to an audience that was not sex-specific.

Romances, however, continued to flourish even in eclipse. Although these novels received little critical attention, publishers and readers kept them alive. The books were written, published, read, and enjoyed whether or not the literary establishment took notice of them and despite the disrepute into which they had fallen.

In the 20th century, gothic and romance novels have had a steady popularity, although only a handful of authors prior to 1960 enjoyed significant public attention, usually through the repeated production of best-sellers or by writing a single block-buster novel with romantic overtones. Writers like Mary Roberts Rinehart, for example, who wrote both romantic mysteries and straight romances, were occasionally so prolific and so successful that they achieved public prominence over a long period of time. Alternatively, a writer such as Margaret Mitchell, author of one exceptionally popular historical romance, might influence scores of lesser writers who never achieved her audience.

For the most part, however, writers of gothic and romantic novels have worked in relative obscurity, attracting a largely female audience of readers who were in on the secret. Both gothics and romances have been categorized by critics and scholars as "mere" love stories or as unrealistic emotional adventures unworthy of serious consideration. Nevertheless, in the early 1980 's two of the five best-selling authors in the world-Barbara Cartland and Janet Daileywere writers of romance.

Gothic and romantic novels are closely related forms of fiction, although within the range of plot conventions there is significant variation in both form and quality. Like other narrative formulas, these books share a common set of interests and take place in similar fictional worlds. Detective and mystery novels, for example, share a fascination with the mythology of crime. Horror novels and science fiction are always interested in the "what-if," the speculation about alien conditions that might impinge upon the rational world. Westerns are concerned with the grand adventure of settling new territory and building a civilization in the wilderness. Spy stories involve the clash of nations and the dirty business of espionage. Romances and gothics take place in a world in which love and domesticity are central to the protagonists' value system and in which conventional conflicts are often centered around the family, however adventurous a novel's plot may be. Suspense may derive from the exciting historical adventure of living in an age of turmoil; it may come from the titillation of the outrageous and horrifying; or it may result from the exquisite conflict between potential lovers. But whatever the ingredients of the individual plot or formula, gothic and romantic novels share a concern with the details of women's personal lives, of mate selection and family formation, of problems between lovers, and of the impact of events upon domestic affairs. Writers of gothics and romances delineate the effect of extreme situations upon men and women in the realm of their conventional domestic concerns; and these novels often-although not always-portray a woman at the center of the action.

Gothic and romantic novels are best seen as parts of a continuum, with books having more or less domestic orientation while still maintaining a commitment to the adventure that can be found within the framework of love and human relationships. The novels of the softcover 
romance series focus upon the private, intimate relationships between lovers, charting the course of the couple's developing feelings until they make a lifetime commitment to each other. These romances are relatively short and resemble each other to a remarkable degree. Even in series novels, however, there is variation in quality and inventiveness. On the opposite end of the spectrum are the more adventurous gothic romances and some historical romances, books in which the characters are threatened not by their personal difficulties but by forces from the world outside. In gothics, potential lovers are kept apart by the machinations of the villain; in historical romances, by the momentous events of the setting in the past.

Series romances aim at an audience that is almost totally female, and the adventure of such novels rarely transcends the issue of the love story; on the other hand, historical romances and family saga romances paint a picture on a wider canvas, with the family rather than an individual woman at the center. The very essence of romance and gothic, however, remains personal, interior, concerned with motivation and action that brings a story to a kind of domestic stasis. The lovers may be separated or united, the family may be intact or disrupted, but the stories are always told against a domestic value system in which characters are rewarded or punished according to conventional moral norms.

The past two decades have seen a dramatic resurgence in the romantic genres. New authors have achieved great success and reprints of older novels have found wide circulation. Romance series have proliferated. In these twenty years, several stages of development in romances have occurred, and although some predict the market will soon collapse, it shows no sign of doing so at present.

In the early 1960 's, the most popular type of fiction in the gothic/romance genre was the novel of romantic suspense, called conveniently by publishers "gothic romance." British writers were most prominent, but their American colleagues were also active. The modern popularity of the gothic romance can probably be most accurately dated from the publication in 1960 of Mistress of Mellyn by Eleanor Burford Hibbert (writing as Victoria Holt). The novel showed its derivation from the Brontës and Daphne du Maurier on almost every page, but it captured the imaginations of readers and writers alike and sparked an upsurge in novels of domestic adventure with sprightly heroines who solved mysteries, protected families and children (not necessarily their own), and won the love of the hero by the final page. For most of that decade, the output of gothic romances remained high, led by Holt, Dorothy Eden, Mary Stewart, and Phyllis Whitney, who were imitated by a host of other writers. As the popularity of the gothic romance grew, other romantic formulas also achieved wider distribution. Historical fiction became more prevalent as publishers searched for new authors while also reprinting older works by such writers as Georgette Heyer and Barbara Cartland. In the latter part of the decade and throughout the 1970's, Regency romances, inspired by Heyer, achieved great success.

Although the gothic and historical romance formulas were the best known, other related types of women's fiction continued to sell. Various series of romantic love stories were popular in Britain, although their distribution in the United States was only a fraction of its current level: The United States was more an audience for romances than a major producer until the first of the erotic romances (or "bodice-rippers") by such American authors as Kathleen Woodiwiss and Rosemary Rogers. The new American romance formula of the 1970's differed from its predecessors in one significant way: the books were much more sexually explicit, featuring heroines whose sexual encounters (in or out of marriage) were more graphically described than in other romances. Before this change, premarital sex had always been a sign that a character was a "fallen woman," similar to the heroine of Kathleen Winsor's Forever Amber, and therefore unworthy of a lasting marriage. By the middle of the decade, however, the erotic romances with either historical or contemporary settings were at center stage, with gothics and straight romances flourishing at a lesser level.

The United States is currently experiencing a high-level competition among publishers of series romances. Toward the end of the decade, the distribution of series romances increased rapidly as the alliance between Mills and Boon in Britain and Harlequin in Canada moved to dominance in the American market. Both those firms had exceptionally effective marketing strategies, selling books by mail order and subscription as well as in retail outlets. As American publishers recognized the success of the Mills and Boon/Harlequin strategy, competition ignited. Simon and Schuster, formerly Harlequin's American distributor, inaugurated the Silhouette Romance series to compete for a share of the lucrative market. In a period of slightly more than two years (1980-82) Silhouette had proliferated into four distinct series of romances, 
including a line for teenagers, a growing segment of the market. Silhouette also lured Mills and Boon authors with some success and began aggressive marketing abroad.

In the same two years, other American publishers followed suit. Dell redesigned its romance series and inaugurated a new line called Candlelight Ecstasy Romances, featuring a more sophisticated and explicit portrayal of sexuality. Jove began its Second Chance at Love series, with heroines who had failed the first time around and now, older and wiser, were ready for a more adult relationship. Bantam, working with the British publishing firm of Robert. Hale, started its Circle of Love series, a more restrained and traditional romance formula than most of the other new lines. Ballantine began a series entitled Life and Love, using older heroines and deriving from the more sophisticated novels of such romance writers as Danielle Steel and Helen Van Slyke.

Each of these new series emphasized the company's product through packaging, formula control enforced by author's "tipsheets," and advertising to promote an image of the series' quality and diversity within a narrow range of predictable plots. The formula control of these publishers relies upon extensive market research aimed at discovering what women want to read so that editors can tailor the product to particular segments of the market. Such publisher control is relatively new in popular fiction. To be sure, series of novels were published in the 19th century, and certain publishing houses have long been known for issuing particular kinds of genre fiction, but the production and marketing of series romance novels represents a more complex development in popular entertainment, comparable to the way television programs are developed, packaged, and sold.

Institutional support for romances has also increased. The Romantic Writers of America was established to provide services to American authors similar to those offered British writers by the older Romantic Novelists Association. Newsletters for fans of romances are proliferating, and conventions for romance readers and authors have been held. Romance is big business today, and the book establishment has had to take notice.

The current situation, however, is probably an aberration, one of those historical moments when the gothic and romance formulas are particularly appealing to a wide audience. Over the past two centuries, these formulas have experienced intermittent waves of prominence that eventually waned, although their production has never entirely disappeared. The novels of especially popular authors remain in print for generations of readers while the more ephemeral works are forgotten.

Only recently, under the influence of the emerging fields of popular culture and women's studies, have scholars begun to look systematically and seriously at gothic and romance writers and readers. Because the area of study is so new, it is hampered by a paucity of bibliographical and critical materials. A reference book like this volume should make basic information available for further scholarly consideration.

-Kay Mussell

\section{READING LIST}

Abartis, Caesarea, "The Ugly-Pretty, Dull-Bright, Weak-Strong Girl in the Gothic Mansion," in Journal of Popular Culture (Bowling Green, Ohio), Fall 1979.

Allen, Richard O., "If You Have Tears: Sentimentalism as Soft Romanticism," in Genre (Plattsburgh, New York), June 1975.

Anderson, Rachel, The Purple Heart Throbs: The Sub-Literature of Love. London, Hodder and Stoughton, 1974.

Bailey, Margaret, “The Women's Magazine Short-Story Heroine in 1957 and 1967," in Journalism Quarterly (Minneapolis), 1969.

Bayer-Berenbaum, Linda, The Gothic Imagination: Expansion in Gothic Literature and Art. Rutherford, New Jersey, Fairleigh Dickinson University Press, 1982. 
Berman, Phyllis, “They Call Us Illegitimate," in Forbes (New York), 6 March 1978.

Britton, Anne, and Marion Collin, Romantic Fiction. London, Boardman, 1960.

Cawelti, John G., Adventure, Mystery, and Romance: Formula Stories as Art and Popular Culture. Chicago, University of Chicago Press, 1976.

Cecil, Mirabel, Heroines in Love 1750-1974. London, Joseph, 1974.

Cornillon, Susan Koppelman, editor, Images of Women in Fiction: Feminist Perspective. Bowling Green, Ohio, Popular Press, 1972.

Douglas, Ann, "Soft-Porn Culture," in New Republic (Washington, D.C.), 30 August 1980.

Drake, Robert Y., Jr., "Tara Twenty Years After,” in Georgia Review (Athens), Summer 1958.

Franzwa, Helen, "Female Roles in Women's Magazine Fiction 1940-1970," in Woman: Dependent or Independent Variable?, edited by Rhoda Kesler Unger and Florence L. Denmark. New York, Psychological Dimensions, 1975.

Greenfeld, Beth, and Juliann E. Fleenor, editors, The Female Gothic. St. Albans, Vermont, Eden Press, 1982.

Hackett, Alice Payne, and James Henry Burke, Eighty Years of Best Sellers. New York, Bowker, 1977.

Harlequin 30th Anniversary 1949-1979: The First 30 Years of the World's Best Romance Fiction. Toronto, Harlequin, 1979.

Hart, James D., The Popular Book: A History of America's Literary Taste. New York, Oxford University Press, 1950.

Harvey, Brett, "Boy Crazy,” in Village Voice (New York), 10 February 1982.

Hoekstra, Ellen, “The Pedestal Myth Reinforced: Women's Magazine Fiction 1900-1920," in New Dimensions in Popular Culture, edited by Russel B. Nye. Bowling Green, Ohio, Popular Press, 1972.

Hofstadter, Beatrice, "Popular Culture and the Romantic Heroine," in American Scholar (Washington, D.C.), Winter 1960-61.

Inge, M. Thomas, editor, Handbook of American Popular Culture 1-2 (includes sections on gothic fiction and romantic fiction). Westport, Connecticut, Greenwood Press, 2 vols., 1979-80.

Mann, Peter H., The Romantic Novel: A Survey of Reading Habits, and A New Survey: The Facts about Romantic Fiction. London, Mills and Boon, 2 vols., 1969-74.

Minundri, Regina, "From Jane to Germaine, with Love," in Library Journal (New York), 15 February 1973.

Moers, Ellen, Literary Women. New York, Doubleday, 1976; London, W.H. Allen, 1977.

Mussell, Kay, "Beautiful and Damned: The Sexual Woman in Modern Gothic Fiction," in Journal of Popular Culture (Bowling Green, Ohio), Summer 1975.

Mussell, Kay, Women's Gothic and Romantic Fiction: A Reference Guide. Westport, Connecticut, Greenwood Press, 1981. 
Nye, Russell B., editor, New Dimensions in Popular Culture. Bowling Green, Ohio, Popular Press, 1972.

Nye, Russel B., The Unembarrassed Muse: The Popular Arts in America. New York, Dial Press, 1970.

O’Toole, Patricia, "Paperback Virgins," in Human Behavior (Los Angeles), February 1979.

Radcliffe, Elsa J., Gothic Novels of the Twentieth Century: An Annotated Bibliography. Metuchen, New Jersey, Scarecrow Press, 1979.

Radway, Janice, "The Utopian Impulse in Popular Literature: Gothic Romances and 'Feminist' Protest," in American Quarterly (Philadelphia), Summer 1981.

Regan, Nancy, “A Home of One's Own: Women's Bodies in Recent Women's Fiction," in Journal of Popular Culture (Bowling Green, Ohio), Spring 1978.

Ritchie, Claire, Writing the Romantic Novel. London, Bond Street, 1962.

Robinson, Lillian S., "On Reading Trash," in Sex, Class, and Culture. Bloomington, Indiana University Press, 1978.

“Romance Fiction: A PW Special Report" edited by Daisy Maryles and Robert Dahlin, in Publishers Weekly (New York), 13 November 1981.

Ruggiero, Josephine A., and Louise C. Weston, "Pulp Feminists," in Human Behavior (Los Angeles), February 1978.

Russ, Joanna, "What Can a Heroine Do? or, Why Women Can't Write," in Images of Women in Fiction: Feminist Perspectives, edited by Susan Koppelman Cornillon. Bowling Green, Ohio, Popular Press, 1972.

Smith, Herbert F., The Popular American Novel 1865-1920. Boston, Twayne, 1980.

Walsh, Mary Roth, "Images of Women Doctors in Popular Fiction," in Journal of Popular Culture (Bowling Green, Ohio), Summer 1978. 


\section{EDITOR'S NOTE}

The selection of writers included in this book is based upon the recommendations of the advisers listed on page xv.

The entry for each writer consists of a biography, a bibliography, and a signed critical essay. Living authors were invited to add a comment on their work. The bibliographies list writings according to the categories of romance and gothic fiction and other publications, and is further sub-divided under pseud onyms. Series characters are indicated for novels. Original British and United States editions of all books have been listed; other editions are listed only if they were the first editions, though an exception has been made to include publications of Harlequin Books (Toronto). As a rule all uncollected short stories published since the entrant's last collection have been listed.

Entries include notations of available bibliographies, manuscript collections, and critical studies. Other critical materials appear in the Reading List of secondary works on the genre.

We would like to thank the entrants and contributors for their patience and cooperation in helping us to compile this book. 


\section{ADVISERS}

Rachel Anderson Mary Cadogan

Barbara Cartland Warren French
Kay Mussell

Victor Neuberg

Elsa J. Radcliffe

Janice Radway

\section{CONTRIBUTORS}

Patricia Altner

Rachel Anderson

Jane S. Bakerman

Earl F. Bargainnier

Melvyn Barnes

Susan B. Berneis

E.F. Bleiler

Marylaine Block

Wendy Bousfield

Susan Branch

Jean Buchanan

Mary Cadogan

Jennifer Cargill

Tessa Rose Chester

Pamela Cleaver

Warren French

Marcia G. Fuchs

Jane Gottschalk

Elizabeth Grey

Marion Hanscom

Marion R. Harris

Barrie Hayne

Joanne Harack Hayne

Michael Held

Allayne C. Heyduk

Joan Hinkemeyer

Louis James

Margaret Jensen

Barbara Kemp

Larry N. Landrum

Lornie Leete-Hodge
Marilyn Lockhart

George C. Longest

Mary C. Lynn

Gina Macdonald

Joan McGrath

Sally Allen McNall

P.R. Meldrum

Arlene Moore

Marilynn Motteler

Kay Mussell

Necia A. Musser

Kim Paynter

Kathy Piehl

Nancy H. Pogel

Janice Radway

Nancy Regan

Bette B. Roberts

Karen Robertson

Lucy Rogers

Josephine A. Ruggiero

Geoffrey A. Sadler

Anne M. Shields

Andrea Lee Shuey

Katherine Staples

Judith Summers

Thomas R. Tietze

W.M. von Zharen

George Walsh

Louise C. Weston

Peggy York

Paula M. Zieselman 